\title{
Effect of Temperature on Dopamine Transporter Function and Intracellular Accumulation of Methamphetamine: Implications for Methamphetamine-Induced Dopaminergic Neurotoxicity
}

\author{
Tao Xie, ${ }^{1}$ Una D. McCann, ${ }^{2}$ Saejeong Kim, ${ }^{1}$ Jie Yuan, ${ }^{1}$ and George A. Ricaurte ${ }^{1}$ \\ Departments of ${ }^{1}$ Neurology, and ${ }^{2}$ Psychiatry and Behavioral Sciences, Johns Hopkins University School of Medicine, \\ Baltimore, Maryland 21224
}

\begin{abstract}
Hyperthermia exacerbates and hypothermia attenuates methamphetamine (METH)-induced dopamine (DA) neurotoxicity. The mechanisms underlying these temperature effects are unknown. Given the essential role of the DA transporter (DAT) in the expression of METH-induced DA neurotoxicity, we hypothesized that the effect of temperature on METH-induced DA neurotoxicity is mediated, at least in part, at the level of the DAT. To test this hypothesis, the effects of small, physiologically relevant temperature changes on DAT function were evaluated in two types of cultured neuronal cells: (1) a neuroblastoma cell line stably transfected with human DAT cDNA and (2) rat embryonic mesencephalic primary cells that naturally express the DAT. Temperatures for studies of DAT function were selected based on core temperature measurements in animals exposed to METH under usual ambient $\left(22^{\circ} \mathrm{C}\right)$ and hypothermic $\left(6^{\circ} \mathrm{C}\right)$ temperature conditions,
\end{abstract}

where METH neurotoxicity was fully expressed and blocked, respectively. DAT function, determined by measuring accumulation of radiolabeled DA and 1-methyl-4-phenylpyridinium $\left(\mathrm{MPP}^{+}\right)$, was found to directly correlate with temperature, with higher levels of substrate uptake at $40^{\circ} \mathrm{C}$, intermediate levels at $37^{\circ} \mathrm{C}$, and lower levels at $34^{\circ} \mathrm{C}$. DAT-mediated accumulation of METH also directly correlated with temperature, with greater accumulation at higher temperatures. These findings indicate that relatively small, physiologically relevant changes in temperature significantly alter DAT function and intracellular METH accumulation, and suggest that the effect of temperature on METHinduced DA neurotoxicity is mediated, at least in part, at the level of the DAT.

Key words: dopamine; dopamine transporter; temperature; methamphetamine; $\mathrm{MPP}^{+}$; neurotoxicity
The psychostimulant methamphetamine (METH) is a potent dopamine (DA) neurotoxin in rodents, nonhuman primates (Gibb et al., 1994; Lew et al., 1998) and, possibly, humans (McCann et al., 1998; Volkow et al., 1999). METH administration leads to longlasting reductions in a number of DA axonal markers including DA, dihydroxyphenylacetic acid (DOPAC), homovanillic acid, tyrosine hydroxylase activity, and the DA transporter (DAT). Recent studies indicate that the striatal vesicular monoamine transporter is also reduced on a long-term basis after METH (Frey et al., 1997; Villemagne et al., 1998). Morphological studies indicate that loss of these presynaptic DA axonal markers is related to destruction of DA axons and axon terminals (Ellison et al., 1978; Lorez, 1981; Ricaurte et al., 1982, 1984; Bowyer et al., 1994; Broening et al., 1997; Fukumura et al., 1998), generally with sparing of DA nerve cell bodies (Ricaurte et al., 1982; Woolverton et al., 1989; but see Sonsalla et al., 1996; Hirata and Cadet, 1997).

The mechanism by which METH induces dopaminergic neurotoxicity is not known. However, there is compelling evidence that the DAT plays an essential role (Marek et al., 1990; Pu et al., 1994; Fumagalli et al., 1998). The DAT is an integral membrane protein of DA neurons that not only serves to inactivate synaptic dopamine by reuptake into presynaptic dopaminergic neurons, but also is known to mediate the pharmacological and reinforcing properties of a number of psychostimulant drugs (Ritz et al., 1987; Koob and Bloom, 1988; Miller et al., 1999). Moreover, intact function of the DAT is essential for the expression of METH-induced DA neurotoxicity. This is evidenced by the fact that DAT inhibitors prevent METH-induced neurotoxicity in vivo (Marek et al., 1990; Pu et al.,

\footnotetext{
Received June 19, 2000; revised Aug. 7, 2000; accepted Aug. 9, 2000.

This work was supported by National Institute on Drug Abuse/National Institutes of Health Grants DA09487, DA05707, DA05938, and DA10217 (G.A.R.). The SK-N-MC cell line was kindly provided by Prof. Marc G. Caron at Duke University.

Correspondence should be addressed to Dr. George A. Ricaurte, Department of Neurology, Johns Hopkins Medical Institutions, 5501 Hopkins Bayview Circle, Room 5B.71E, Baltimore, MD 21224. E-mail: Ricaurte@jhmi.edu.

Copyright (C) 2000 Society for Neuroscience $0270-6474 / 00 / 207838-08 \$ 15.00 / 0$
}

1994) and by the observation that homozygotic (-/-) DAT knockout mice are resistant to METH-induced DA neurotoxicity, wildtypes $(+/+)$ are fully susceptible, and heterozygotes $(+/-)$ develop partial dopaminergic lesions after METH administration (Fumagalli et al., 1998).

Temperature has been found to markedly influence METHinduced DA neurotoxicity. In particular, hyperthermia consistently exacerbates METH-induced DA neurotoxicity, whereas hypothermia is neuroprotective (Bowyer et al., 1992, 1994; Ali et al., 1994; Albers and Sonsalla, 1995; Cappon et al., 1997; Callahan and Ricaurte 1998; Clausing and Bowyer, 1999). Furthermore, a broad range of pharmacological agents that protect against METHinduced DA neurotoxicity appears to do so by producing hypothermia (Bowyer et al., 1992, 1994; Ali et al., 1994; Miller and O'Callaghan, 1994; Albers and Sonsalla, 1995; Callahan and Ricaurte, 1998). The mechanisms underlying these temperature effects are unknown.

We hypothesized that the prominent effect of temperature on METH-induced DA neurotoxicity involved the DAT, possibly by altering its function. To test this hypothesis, we first ascertained core temperatures of mice treated with METH at usual room temperature $\left(22^{\circ} \mathrm{C}\right.$, a temperature in which $\mathrm{METH}$-induced neurotoxicity is fully expressed), as well as at a lower ambient temperature $\left(6^{\circ} \mathrm{C}\right.$, known to protect from METH-induced DA neurotoxicity). Using these core temperatures as a guide for in vitro studies, the effects of temperature on DAT function were examined in two separate neuronal culture systems containing the DAT.

\section{MATERIALS AND METHODS}

Drugs and chemicals. $\left[{ }^{3} \mathrm{H}\right] \mathrm{DA}$ and $\left[{ }^{3} \mathrm{H}\right] \mathrm{MPP}{ }^{+}$, as hydrochloride salts, were purchased from New England Nuclear (Boston, MA). $\left[{ }^{3} \mathrm{H}\right]$ Methamphetamine hydrochloride and cocaine hydrochloride were obtained from the National Institute on Drug Abuse (Bethesda, MD). Dopamine hydrochloride and polyornithine were purchased from Sigma (St. Louis, MO), and $\mathrm{MPP}^{+}$was obtained from Aldrich (Milwaukee, WI). All the other cell culture media and chemicals were purchased from Life Technologies (Grand Island, NY).

Animals. Male albino Swiss-Webster mice weighing 20-25 gm and 

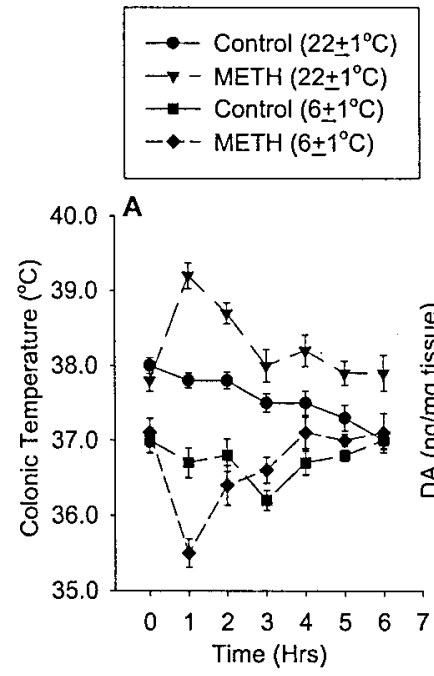
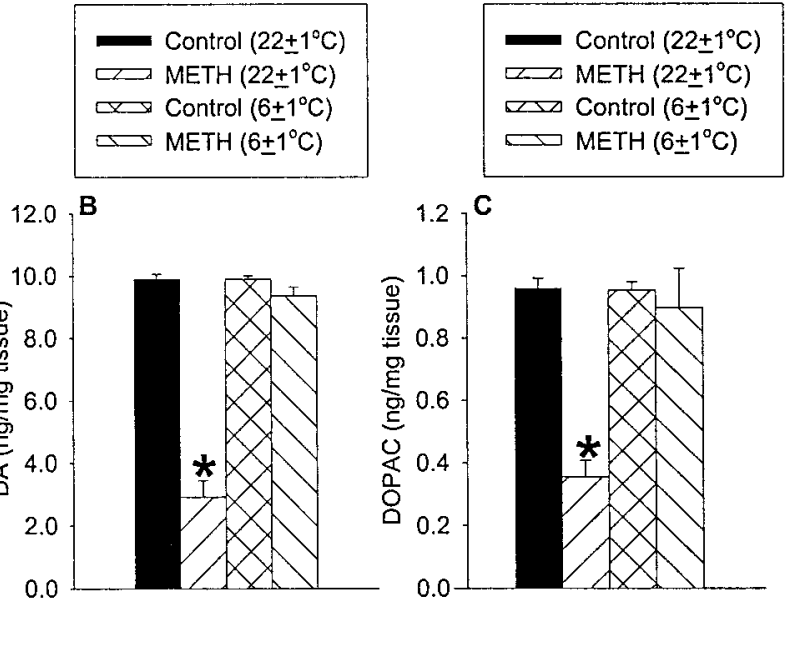

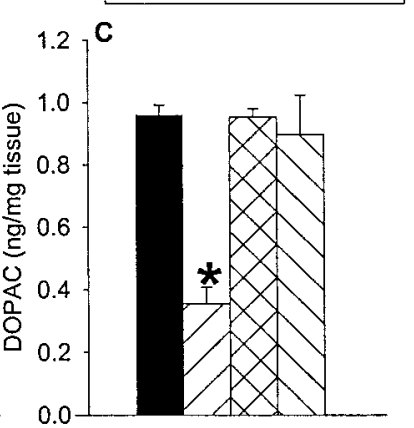

Figure 1. Effect of METH on core temperature $(A)$, striatal DA levels $(B)$, and striatal DOPAC levels $(C)$ in mice. Mice were treated with either METH $(45 \mathrm{mg} / \mathrm{kg}$, s.c.) or same volume of saline at two different ambient temperatures $(22 \pm 1$ and $6 \pm 1^{\circ} \mathrm{C}$ ) and killed 1 week later. Values shown represent the means \pm SEM of six mice per group. *Designates significant difference compared to control; $p<0.05$, determined by individual comparison after ANOVA showed an $F$ value with $p<0.05$. pregnant Sprague Dawley rats (day 14 of gestation) weighing 250-300 gm were purchased from Taconic (Germantown, NY). Animals were housed individually in clear acrylic cages in a temperature-controlled room before use $\left(22 \pm 1^{\circ} \mathrm{C}\right)$. Experimental protocols were approved by the Animal Care and Use Committee of the Johns Hopkins Medical Institutions. The facility for housing and care of the animals is accredited by the American Association for the Assessment and Accreditation of Laboratory Animal Care.

Temperature studies. Two groups ( $n=6$ per group) of Swiss-Webster mice were treated with either saline or METH $(45 \mathrm{mg} / \mathrm{kg}$, s.c. $)$ at room temperature $\left(22 \pm 1^{\circ} \mathrm{C}\right)$. Another two groups of mice were put in a cold room $\left(6 \pm 1^{\circ} \mathrm{C}\right) 30 \mathrm{~min}$ before receiving the same METH regimen, and they were maintained in the cold room for an additional $6 \mathrm{hr}$. These temperatures were chosen because at $22^{\circ} \mathrm{C}, \mathrm{METH}$-induced neurotoxicity is fully expressed, whereas at $6^{\circ} \mathrm{C}$, there is significant protection from METH-induced DA neurotoxicity (Bowyer et al., 1992; Ali et al., 1994; see below). Rectal temperatures were measured every hour for $6 \mathrm{hr}$ using a BAT-12 thermometer coupled to a RET-3 mouse rectal probe with the resolution of $0.1^{\circ} \mathrm{C}$ (Physitemp Instruments, Clifton, NJ). All mice were killed 1 week after treatment for measurement of brain biogenic amines.

Determination of brain biogenic amine concentrations. Levels of DA and DOPAC were determined by means of HPLC coupled with electrochemical detection, as described previously (Ricaurte et al., 1992).

HDAT-SK- $N$-MC cell culture. The hDAT-SK-N-MC, a neuroblastoma cell line (SK-N-MC) stably transfected with the human DAT cDNA, constitutively expresses the DAT (Pifl et al., 1993). These cells were used for the present studies because of their established validity for studying the effects of DA neurotoxins (Pifl et al., 1993). Cells were grown in minimum essential medium Eagle containing $1.5 \mathrm{gm} / 1$ sodium bicarbonate, $2 \mathrm{~mm}$ L-glutamine, $0.1 \mathrm{~mm}$ nonessential amino acids, $1.0 \mathrm{~mm}$ sodium pyruvate, $10 \%$ heat-inactivated fetal bovine serum, $100 \mathrm{U} / \mathrm{ml}$ of penicillin, and 100 $\mu \mathrm{g} / \mathrm{ml}$ of streptomycin at $37^{\circ} \mathrm{C}$ in humidified air of $5 \% \mathrm{CO}_{2}$. For assays, cells were plated into 24 -well plates in a final volume of $400 \mu \mathrm{l}$ and nearly confluent $2 \mathrm{~d}$ later, before experimental use.

Rat embryonic mesencephalic cell culture. Rat embryonic mesencephalic tissues were obtained from pregnant Sprague Dawley rats on day 14 of gestation. Briefly, as described by Shimoda et al. (1992), the ventral mesencephalon was dissected free without the membrane covering, and collected in $\mathrm{Ca}^{2+}$ and $\mathrm{Mg}^{2+}$-free Dulbecco's PBS at $4^{\circ} \mathrm{C}$. The tissue was minced and dissociated into single cells by mild trituration with a smallbore Pasteur pipette. The cell suspension was plated in polyornithinecoated $(0.1 \mathrm{mg} / \mathrm{ml}) 48$-well Falcon plates at a density of $0.65 \times 10^{6}$ cells per $\mathrm{cm}^{2}$. Cultures were maintained in a medium consisting of DMEM/F-12 medium (1:1) supplemented with $6 \mathrm{mg} / \mathrm{ml}$ glucose, $15 \%$ horse serum, and $2 \mathrm{~mm}$ glutamine. The cultures were incubated at $37^{\circ} \mathrm{C}$ in humidified air of $5 \% \mathrm{CO}_{2}$. On day 5 in vitro, the cultures were treated for $24 \mathrm{hr}$ with fluorodeoxyuridine $(13 \mu \mathrm{g} / \mathrm{ml})$ and uridine $(33 \mu \mathrm{g} / \mathrm{ml})$ to prevent excessive proliferation of non-neuronal cells. The cells were cultured for $14 \mathrm{~d}$ before experimental use.

$\left.{ }^{3} \mathrm{H}\right] \mathrm{DA}$ uptake. First, the culture medium was completely removed from the plate well. Krebs'-Ringer's-Phosphate (KRP) buffer (pH 7.4, containing $136 \mathrm{~mm} \mathrm{NaCl}, 4.8 \mathrm{mM} \mathrm{KCl}, 1.2 \mathrm{mM} \mathrm{MgSO}_{4}, 1.4 \mathrm{mM} \mathrm{CaCl}_{2}, 10 \mathrm{~mm}$ glucose, $1 \mathrm{~mm}$ ascorbate, $140 \mu \mathrm{M}$ EDTA and $120 \mu \mathrm{M}$ pargyline) was then added to each well ( $400 \mu \mathrm{l}$ for hDAT-SK-N-MC cells in 24 -well plate and $200 \mu \mathrm{l}$ for rat embryonic mesencephalic cells in 48-well plate). Cells were preincubated at various predetermined temperatures $\left(34,37\right.$, or $\left.40^{\circ} \mathrm{C}\right)$ for $5 \mathrm{~min}$, in the presence or absence of $200 \mu \mathrm{M}$ cocaine. DA uptake was initiated by the addition of $1 / 10$ total volume of a $10 \times$ solution of $\left[{ }^{3} \mathrm{H}\right] \mathrm{DA}$ resulting in a final concentration of $24 \mathrm{~nm}$. For kinetic studies of $\left[{ }^{3} \mathrm{H}\right] \mathrm{DA}$ uptake by hDAT-SK-N-MC cells, $1 / 10$ total volume of $240 \mathrm{~nm}\left[{ }^{3} \mathrm{H}\right] \mathrm{DA}$ was added to a range of unlabeled DA $(0,0.1,0.3,1,3,10$, and $30 \mu \mathrm{M})$ in KRP. In rat embryonic mesencephalic cells, $24 \mathrm{~nm}$ of $\left[{ }^{3} \mathrm{H}\right] \mathrm{DA}$ alone was used to confirm and extend data obtained from hDAT-SK-N-MC cells. Uptake was allowed to proceed for $6 \mathrm{~min}$ and stopped by rapid removal of KRP. The cells were rapidly washed twice with same volume of cold KRP, and then solubilized in $1 \%$ SDS at room temperature for $2 \mathrm{hr}$. Cell lysates were placed into scintillation vials containing $5 \mathrm{ml}$ of scintillation fluid and vortexed for $15 \mathrm{sec}$. Radioactivity was counted at $\sim 48 \%$ efficiency on a Packard 1500 scintillation counter with on board quench correction. The difference between total uptake (in the absence of cocaine) and nonspecific uptake (in the presence of $200 \mu \mathrm{M}$ cocaine) was defined as specific DATmediated uptake.

$\left[{ }^{3} \mathrm{H}\right] \mathrm{MPP}{ }^{+}$uptake. The final concentration of $4 \mathrm{nM}$ of $\left[{ }^{3} \mathrm{H}\right] \mathrm{MPP}^{+}$was mixed with a range of unlabeled $\mathrm{MPP}^{+}(1,10$, and $100 \mu \mathrm{M})$ in hDAT-SK$\mathrm{N}-\mathrm{MC}$ cells and final concentration of $13 \mathrm{nM}$ of $\left[{ }^{3} \mathrm{H}\right] \mathrm{MPP}^{+}$was mixed with a range of unlabeled $\mathrm{MPP}^{+}(1,10$, and $100 \mu \mathrm{M})$ in the embryonic rat mesencephalic cells. The rest of the assay conditions were similar to those used to measure $\left[{ }^{3} \mathrm{H}\right] \mathrm{DA}$ uptake.

$\left[{ }^{3} H\right] M E T H$ accumulation. Time course and dose-effect (concentrationuptake) studies were first performed to determine the best conditions to study the effects of temperature DAT-mediated METH accumulation, because the effects of temperature on cell viability were unknown, and there were previous reports of two concentration-dependent mechanisms for amphetamine to enter cells (Liang and Rutledge, 1982; Zaczek et al., $1991 \mathrm{a}, \mathrm{b})$. In the time course study, final concentrations of $20 \mathrm{~nm}$ $\left[{ }^{3} \mathrm{H}\right] \mathrm{METH}$ and $1 \mu \mathrm{M}$ unlabeled METH were incubated at $37^{\circ} \mathrm{C}$ in the presence or absence of $200 \mu \mathrm{M}$ cocaine for different time periods $(0,3,5$, $7,9,15,20$, and $25 \mathrm{~min}$ ) in hDAT-SK-N-MC cells. In the dose-effect study, a final concentration of $20 \mathrm{~nm}$ of $\left[{ }^{3} \mathrm{H}\right] \mathrm{METH}$ was incubated at $37^{\circ} \mathrm{C}$ for 6 min (the best time point derived from the above time course study) with a range of unlabeled METH concentrations $(0,0.1,1,10,100$, and $1000 \mu \mathrm{M})$ in the presence or absence of $200 \mu \mathrm{M}$ cocaine in hDAT-SK-N-MC cells and rat embryonic mesencephalon cells. Based on the above data, the effect of temperature $\left(34,37\right.$, and $\left.40^{\circ} \mathrm{C}\right)$ on the DAT-mediated intracellular METH accumulation was tested in hDAT-SK-N-MC cells and rat embryonic mesencephalic cells using a range of unlabeled METH $(0.1,1$, and $10 \mu \mathrm{M})$ and $20 \mathrm{nM}\left[{ }^{3} \mathrm{H}\right] \mathrm{METH}$ with the incubation time of $6 \mathrm{~min}$. The rest of the assay conditions were similar to those used to measure $\left[{ }^{3} \mathrm{H}\right] \mathrm{DA}$ uptake.

Data analysis. Substrate uptake by the DAT was analyzed using old saturation method of the iterative nonlinear computer fitting program (Kell-Radlig) to estimate $V_{\max }$ (maximum DA uptake rate of the DAT) and $K_{\mathrm{m}}$ (inverse of dopamine affinity for DAT) values, or using the absolute value or the percentage. Data were analyzed by one-way ANOVA, followed by Duncan's multiple range post hoc comparisons, where appropriate. Results were considered significant if the $p$ value was $<0.05$, using a two-tailed test. Data analysis was performed using the Statistical Program for the Social Sciences (SPSS for Windows, Release 6).

\section{RESULTS}

\section{Determination of temperatures needed for in vitro studies}

Mice treated with METH at an ambient temperature of $22^{\circ} \mathrm{C}$ had increases in core temperature up to $39.5^{\circ} \mathrm{C}$ (Fig. $1 \mathrm{~A}$ ). As expected, these animals showed an approximate $70 \%$ depletion of DA axonal markers 1 week later (Fig. $1 B, C$ ). By contrast, administration of $\mathrm{METH}$ at $6^{\circ} \mathrm{C}$ was associated with decreases in core temperatures as low as $35.5^{\circ} \mathrm{C}$ (Fig. $1 \mathrm{~A}$ ), and no evidence of DA neurotoxicity (Fig. $1 B, C$ ). In addition to confirming the marked influence that temperature can have on METH neurotoxicity (see introductory 


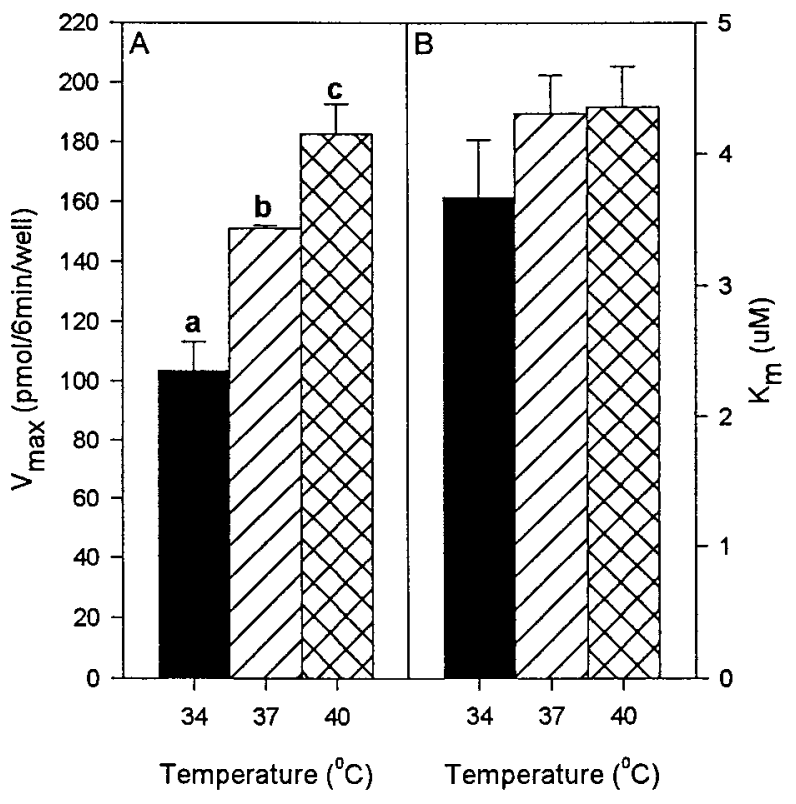

Figure 2. Effect of temperature on $\left[{ }^{3} \mathrm{H}\right] \mathrm{DA}$ uptake by hDAT-SK-N-MC cells. The experiment was performed as described in Materials and Methods. The $V_{\max }$ of $\left[{ }^{3} \mathrm{H}\right] \mathrm{DA}$ uptake increased significantly with increased temperature $(A)$. There was no significant change in the $K_{\mathrm{m}}(B)$. Values shown in $A$ and $B$ represent the means \pm SEM of at least three independent experiments, each performed in triplicate. Results were considered significant if $p<0.05$, one-way ANOVA. ${ }^{\text {a }}$ Designates significant difference from 37 and $40^{\circ} \mathrm{C}$. b ${ }^{b}$ Designates significant difference from 34 and $40^{\circ} \mathrm{C}$. ${ }^{\circ}$ Designates significant difference from 34 and $37^{\circ} \mathrm{C}$.

remarks), these results indicated that a temperature range from 34 to $40^{\circ} \mathrm{C}$ would be most appropriate for in vitro studies on the effect of temperature on DAT function in the context of METH-induced DA neurotoxicity.

\section{Effect of temperature on $\left[{ }^{3} \mathrm{H}\right] \mathrm{DA}$ uptake by hDAT-SK-N-MC cells}

Measurement of DAT function in hDAT-SK-N-MC cells at various temperatures $\left(34,37\right.$, and $40^{\circ} \mathrm{C}$; based on experiments described above) showed that the $V_{\max }$ of DA uptake was significantly greater at higher temperatures, with $103 \pm 10 \mathrm{pmol} / \mathrm{well} / 6 \mathrm{~min}$ at $34^{\circ} \mathrm{C}$, $151 \pm 12 \mathrm{pmol} / \mathrm{well} / 6 \mathrm{~min}$ at $37^{\circ} \mathrm{C}$, and $183 \pm 10 \mathrm{pmol} / \mathrm{well} / 6 \mathrm{~min}$ at $40^{\circ} \mathrm{C}$ (Figs. $2 A, 3$ ). The $K_{\mathrm{m}}$, reflecting the affinity of the DAT for its substrate DA was not significantly different at any of the temperatures tested (Figs. 2B, 3). These data suggest that higher temperatures increases the $V_{\max }$ of DA uptake without changing the affinity of DAT for DA.

\section{Effect of temperature on $\left[{ }^{3} \mathrm{H}\right] \mathrm{DA}$ uptake by embryonic mesencephalic cells}

Using similar conditions as those used in hDAT-SK-N-MC cells, we found that DAT function, as reflected by $\left[{ }^{3} \mathrm{H}\right] \mathrm{DA}$ uptake, was significantly greater at higher temperatures in embryonic mesencephalic cells that naturally express the DAT (Fig. 4), suggesting that the function of the DAT is greater at higher temperature regardless of cell model used.

\section{Effect of temperature on [3H]MPP ${ }^{+}$uptake by hDAT-SK-} $\mathrm{N}-\mathrm{MC}$ cells and embryonic mesencephalic cells

To determine whether findings with $\left[{ }^{3} \mathrm{H}\right] \mathrm{DA}$ generalized to another DAT substrate, additional studies were conducted with the known DA neurotoxin, MPP ${ }^{+}$. As with $\left[{ }^{3} \mathrm{H}\right] \mathrm{DA}$, we found significantly greater $\left[{ }^{3} \mathrm{H}\right] \mathrm{MPP}^{+}$uptake at higher temperatures (Fig. 5). This was the case in both cell culture models used (hDAT-SK$\mathrm{N}-\mathrm{MC}$ cells, Fig. $5 A$; embryonic mesencephalic cells, Fig. 5B), suggesting the function of the DAT is greater at higher temperature regardless of cell model or DAT substrate used.

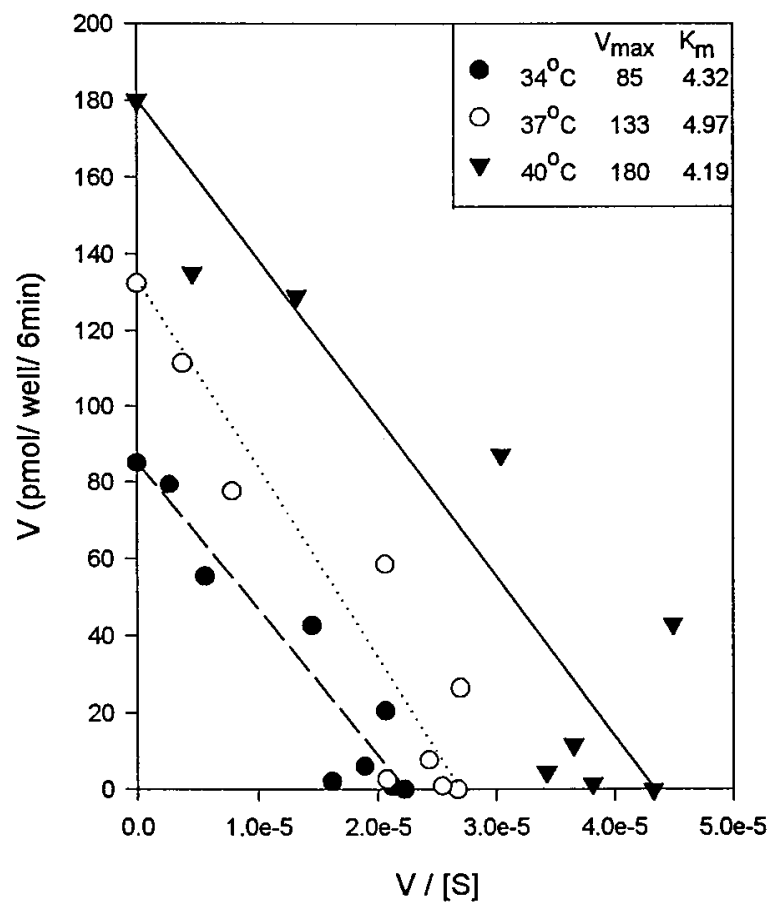

Figure 3. Representative Eadie-Hofstee plot showing the effect of temperature on the kinetic parameters of $\left[{ }^{3} \mathrm{H}\right] \mathrm{DA}$ uptake by hDAT-SK-N-MC cells. The Eadie-Hofstee plot shows data from one of three experiments, with samples run in triplicate.

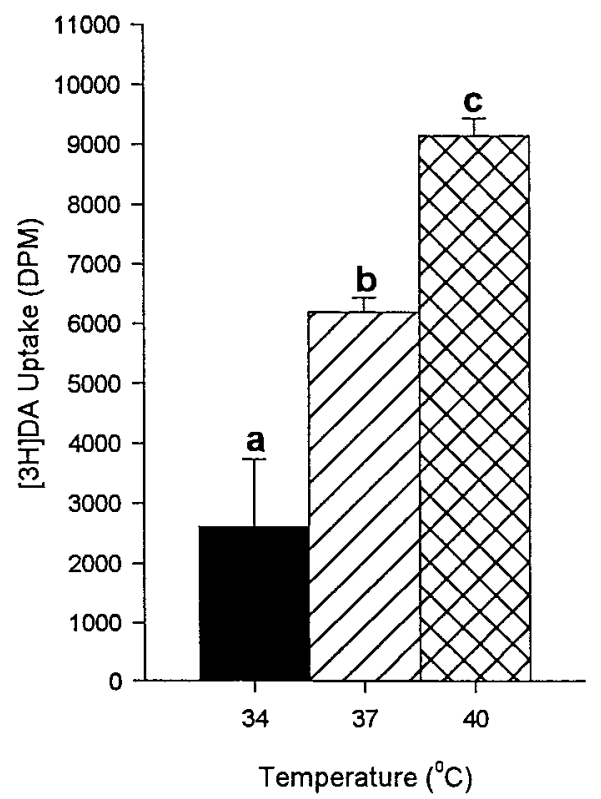

Figure 4. Effect of temperature on $\left[{ }^{3} \mathrm{H}\right] \mathrm{DA}$ uptake in embryonic mesencephalic cells. The experiment was performed as described in Materials and Methods. [ $\left.{ }^{3} \mathrm{H}\right] \mathrm{DA}$ uptake increased significantly with increased temperature. Values shown represent the means \pm SEM of at least three independent experiments, each performed in triplicate. Results were considered significant if $p<0.05$, one-way ANOVA. ${ }^{a}$ Designates significant difference from 37 and $40^{\circ} \mathrm{C}$. ${ }^{b}$ Designates significant difference from 34 and $40^{\circ} \mathrm{C}$. ${ }^{c}$ Designates significant difference from 34 and $37^{\circ} \mathrm{C}$.

\section{Effect of temperature on $\left[{ }^{3} \mathrm{H}\right]$ METH accumulation by hDAT-SK-N-MC cells and embryonic mesencephalic cells}

Having shown that DAT function was significantly higher at $40^{\circ} \mathrm{C}$, intermediate at $37^{\circ} \mathrm{C}$, and lower at $34^{\circ} \mathrm{C}$, we needed to further determine whether DAT-mediated METH accumulation was sim- 


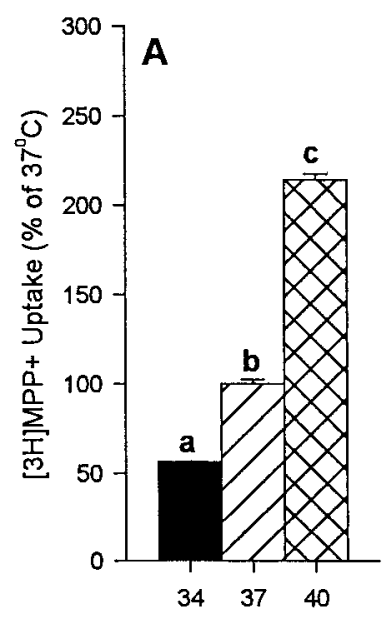

Temperature $\left({ }^{\circ} \mathrm{C}\right)$

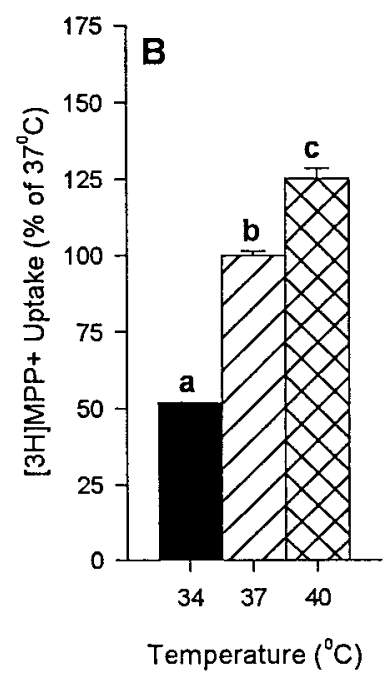

Figure 5. Effect of temperature on $\left[{ }^{3} \mathrm{H}\right] \mathrm{MPP}^{+}$uptake in hDAT-SK-N-MC cells $(A)$ and embryonic mesencephalic cells $(B)$. Significant increases in $\left[{ }^{3} \mathrm{H}\right] \mathrm{MPP}^{+}$uptake were observed at higher temperatures at all concentrations tested, ranging from 1 to $100 \mu \mathrm{M}$ of cold $\mathrm{MPP}^{+}$in the presence of 4 nM $\left[{ }^{3} \mathrm{H}\right] \mathrm{MPP}^{+}$or $13 \mathrm{~nm}\left[{ }^{3} \mathrm{H}\right] \mathrm{MPP}^{+}$, as described in Materials and Methods. The figure depicts the results of a representative experiment using 10 $\mu \mathrm{M}$ of cold $\mathrm{MPP}^{+}$in the presence of $4 \mathrm{nM}\left[{ }^{3} \mathrm{H}\right] \mathrm{MPP}^{+}(A)$ or $13 \mathrm{nM}$ $\left[{ }^{3} \mathrm{H}\right] \mathrm{MPP}^{+}(B)$. Values shown represent the mean \pm SEM of at least three independent experiments, each performed in triplicate. Results were considered significant if $p<0.05$, one-way ANOVA. ${ }^{\text {a}}$ Designates significant difference from 37 and $40^{\circ} \mathrm{C}$. ${ }^{\circ}$ Designates significant difference from 34 and $40^{\circ} \mathrm{C}$. 'Designates significant difference from 34 and $37^{\circ} \mathrm{C}$.

ilarly influenced by temperature, because this would help link the findings to METH-induced DA neurotoxicity. As noted in Materials and Methods, time course and dose-effect studies were first performed to determine the best conditions in which to study the effect of temperature on DAT-mediated METH accumulation. In a time course study, a positive curvilinear relationship between specific METH accumulation and incubation time was found in the first 9 min, reaching a plateau afterward (Fig. 6). Based on these observations, a 6 min incubation was chosen for subsequent studies because a $6 \mathrm{~min}$ incubation had also been used for the studies of DA and $\mathrm{MPP}^{+}$uptake. In the dose-effect study, DAT-mediated METH accumulation was found only at concentrations of METH that did not exceed $10 \mu \mathrm{M}$ (Fig. 7). This was the case in both hDAT-SK-N-MC cells (Fig. 7A) and embryonic mesencephalic cells (Fig. 7B). At higher concentrations (100 and $1000 \mu \mathrm{M}$ ), METH accumulation largely could not be blocked by cocaine, suggesting that it was largely by passive diffusion (Fig. 7A,B). Because these results were in agreement with those of previous studies examining $\left[{ }^{3} \mathrm{H}\right]$ amphetamine accumulation by rat striatal synaptosomes (Liang and Rutledge, 1982; Zaczek et al., 1991a,b), METH concentrations not exceeding $10 \mu \mathrm{M}$ were used in subsequent studies designed to test the effect of temperature on DATmediated intracellular METH accumulation.

Increased temperature $\left(34,37\right.$, and $\left.40^{\circ} \mathrm{C}\right)$ was associated with greater $\left[{ }^{3} \mathrm{H}\right] \mathrm{METH}$ accumulation at all concentrations of METH tested (final concentration of $0.1,1$, and $10 \mu \mathrm{M}$ cold METH mixed with $\left.20 \mathrm{~nm}\left[{ }^{3} \mathrm{H}\right] \mathrm{METH}\right)$. This was the case in both hDAT-SK$\mathrm{N}-\mathrm{MC}$ cells (Fig. $8 A-C$, respectively) and embryonic mesencephalic cells (Fig. $9 A-C$, respectively), indicating that DATmediated METH accumulation is also directly correlated with temperature, with significantly higher accumulation at $40^{\circ} \mathrm{C}$, intermediate accumulation at $37^{\circ} \mathrm{C}$, and lowest accumulation at $34^{\circ} \mathrm{C}$.

\section{DISCUSSION}

The present results indicate that small, stepwise increases in temperature (ranging from 34 to $40^{\circ} \mathrm{C}$ ) are directly correlated with significant increases in DAT function and DAT-mediated METH cellular accumulation. The fact that similar observations were made using three different DAT substrates $\left(\mathrm{DA}, \mathrm{MPP}^{+}\right.$, and

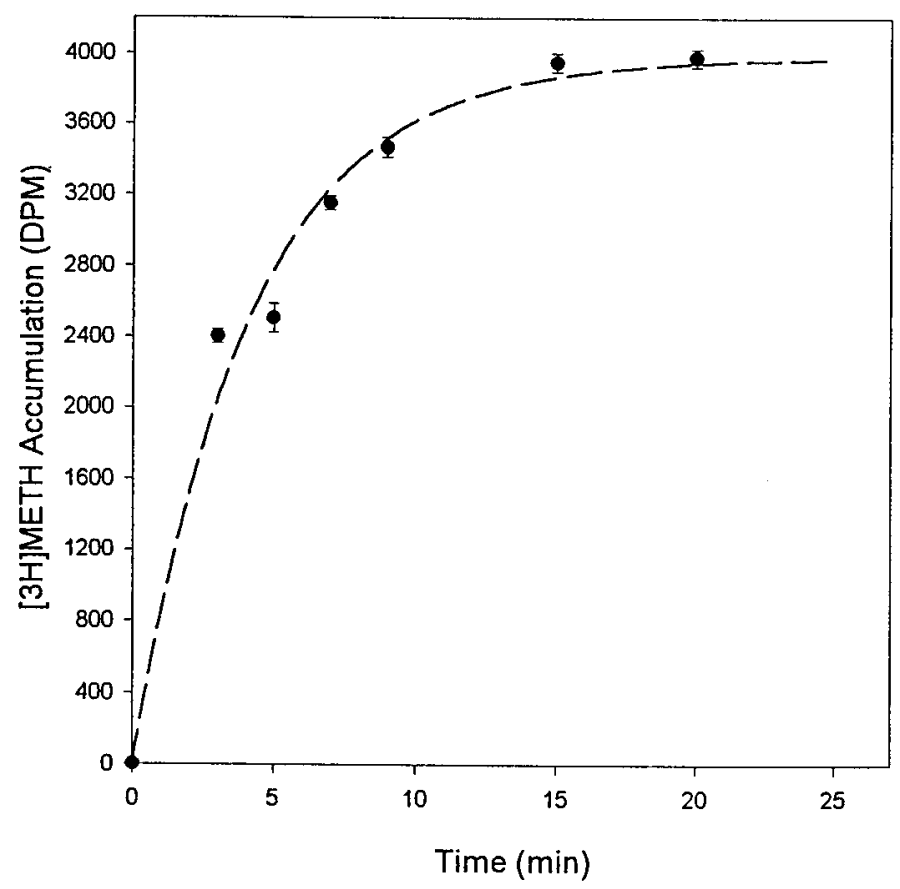

Figure 6. Time course study of $\left[{ }^{3} \mathrm{H}\right] \mathrm{METH}$ accumulation by hDAT-SKN-MC cells. The experiment was performed three times, as described in Materials and Methods. Values shown represent the mean \pm SEM, with each time point run in triplicate.

METH) in two distinct neuronal cell culture models suggests that the findings are not related to peculiarities of an individual substrate or cell culture model and strongly support the validity of the observations. Because changes in temperature can profoundly influence METH neurotoxicity (Bowyer et al., 1992, 1994; Ali et al., 1994; Albers and Sonsalla, 1995; Cappon et al., 1997; Callahan and Ricaurte 1998; Clausing and Bowyer, 1999) and because the DAT plays an essential role in METH-induced DA neurotoxicity (Marek et al., 1990; Pu et al., 1994; Fumagalli et al., 1998), the effect of temperature on METH-induced DA neurotoxicity is likely to be mediated, at least in part, at the level of the DAT.

Whereas previous studies have demonstrated that DAT function is decreased at extremely low temperatures $\left(4^{\circ} \mathrm{C}\right)$ (Shimada et al., 1991), this is the first study to demonstrate that small changes in temperature that are in close proximity to normal core temperature $\left(37^{\circ} \mathrm{C}\right)$ significantly influence DAT function. The importance of this finding is underscored by the fact that the temperature range used in the present studies was selected based on core temperature measurements from METH-treated animals. Thus, the "high" temperature $\left(40^{\circ} \mathrm{C}\right)$ mimicked the core temperature of animals in which METH toxicity was fully expressed, whereas the "low" temperature $\left(34^{\circ} \mathrm{C}\right)$ mimicked the core temperature of animals that were fully protected by reducing the ambient temperature (Fig. 1). Notably, these temperatures also reflect brain temperature, which closely parallels core temperature (Clausing and Bowyer, 1999).

The present results also indicate that increased temperature is associated with greater DAT-mediated METH accumulation (Figs. $8,9)$. This observation is consistent with the hypothesis that temperature influences METH neurotoxicity, at least in part, by altering DAT function, possibly by increasing intraneuronal METH concentrations. It is well established that METH-induced DA neurotoxicity is dose-dependent and that increased striatal levels of amphetamines are associated with increased neurotoxicity (Ricaurte et al., 1983; see Seiden and Ricaurte, 1987). Furthermore, it is known that the DAT plays an essential role in METH-induced dopaminergic neurotoxicity (Marek et al., 1990; Pu et al., 1994; Fumagalli et al., 1998). Collectively, these observations suggest that transport of METH into cells via the DAT or an interaction between METH and the DAT is necessary (although perhaps not 
Figure 7. Relationship between METH concentration and DAT-mediated METH accumulation in hDAT-SK-N-MC cells $(A)$ and embryonic mesencephalic cells $(B)$. The experiment was performed as described in Materials and Methods. Accumulation of $20 \mathrm{nM}\left[{ }^{3} \mathrm{H}\right] \mathrm{METH}$ was measured in the presence of increasing concentrations of cold METH and in the presence and absence of cocaine $(200 \mu \mathrm{M})$. Note that as the concentration of cold METH increases, the amount of DAT-mediated METH accumulation (the area between the lines for absence and presence of cocaine) decreases in both cell models. The non-DAT-mediated METH accumulation (the area below the line for the presence of cocaine) is virtually the same in both cell models. Values shown represent the means \pm SEM of at least three independent experiments, each performed in triplicate. The error bars are too small to be seen. Results were considered significant if $p<0.05$, one-way ANOVA. *Designates significant DAT-mediated METH accumulation compared with the value at the METH concentration of $100 \mu \mathrm{M}$.

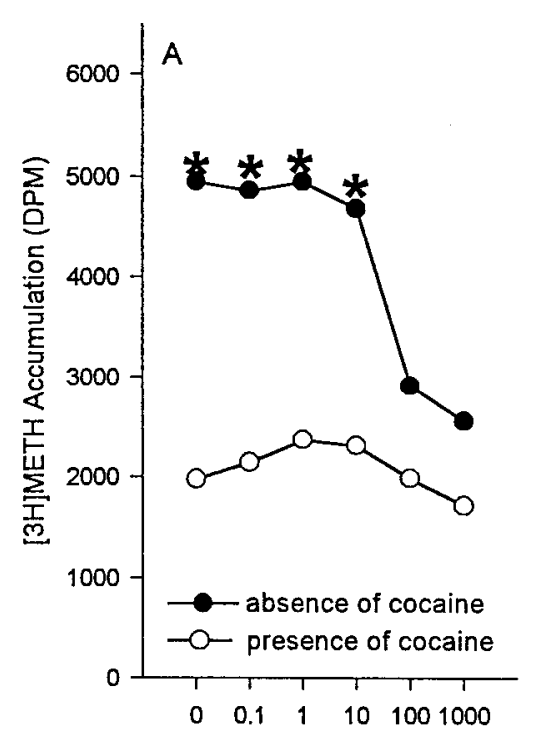

Concentration of Cold METH (UM)

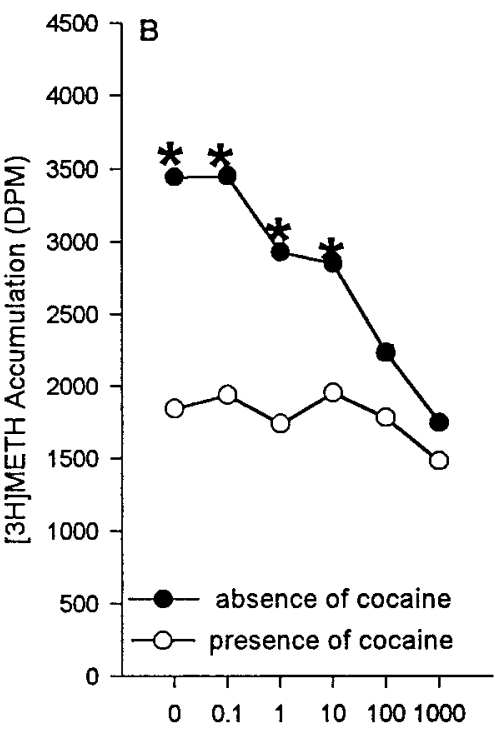

Concentration of Cold METH (UM) sufficient) for the expression of METH neurotoxicity. The fact that there are brain regions in the hyperthermic animal that contain the DAT yet do not sustain the same degree of neural injury as the striatum (e.g., nucleus accumbens, hypothalamus, and substantia nigra) (Broening et al., 1997) suggests that regional differences in DAT function or factors beyond the DAT (e.g., age, species or metabolic differences) may also modify the neurotoxicity of METH and related drugs (Broening et al., 1995; Cappon et al., 1997).

Consistent with previous reports using amphetamine as a DAT substrate (Liang and Rutledge, 1982; Zaczek et al., 1991a,b), the present results indicate that the nature of the interaction between METH and DA neurons is dependent on the concentration of METH tested. Specifically, at lower concentrations (20 nM to 10 $\mu \mathrm{M})$, the bulk of METH appears to enter DA cells via the DAT, and is thus sensitive to cocaine inhibition. In contrast, at higher concentrations (100-1000 $\mu \mathrm{M})$, the bulk of METH appears to enter DA cells by passive diffusion, because most of it can no longer be blocked by cocaine. The finding that DAT-mediated intracellular METH accumulation was strongly influenced by temperature provides additional indication that transport of METH into cells through the DAT or an interaction between METH and the DAT plays a role in METH neurotoxicity. Notably, the concentrations of METH used for DAT-mediated uptake in the present study
$(0.1-10 \mu \mathrm{M})$ are in the range of those found in the setting of METH neurotoxicity in vivo (Clausing and Bowyer, 1999).

Ideally, to directly test the hypothesis that increased uptake of METH at higher temperatures is responsible for increased DA neurotoxicity observed at higher ambient temperatures, in vivo and/or DA cell culture studies should be performed to demonstrate that increased concentrations of METH within DA terminals are associated with increased METH neurotoxicity. However, because only a very small fraction of nerve terminals in the striatum are dopaminergic, in vivo studies using the entire striatum of intact animals stand a high chance of yielding false negative results. Moreover, they would not permit conclusions regarding changes in METH concentrations within DA nerve terminals. Likewise, neurotoxicity studies using DA cells in culture would be inconclusive, because efforts to protect DA cells in culture from METH-induced neurotoxicity with DAT blockers have thus far been unsuccessful (Callahan et al., 2000). In addition, these studies would require prolonged incubations (3-5 d) (Bennett et al., 1993, 1998; Cubells et al., 1994) at nonphysiological temperatures, a process that would be associated with exceedingly high rates of cell death unrelated to METH. In this regard, however, it is noteworthy that in a recently developed in vitro model, small increments in temperature identical to those used in the present study have been linked to increases in
Figure 8. Effect of temperature on DAT-mediated [ $\left.{ }^{3} \mathrm{H}\right] \mathrm{METH}$ accumulation in hDAT-SK-N-MC cells. The experiment was performed as described in Materials and Methods. Significantly greater METH accumulation was observed at higher temperatures at all concentrations of METH $(0.1,1$, and $10 \mu \mathrm{M} ; A-C$, respectively) tested in the presence of $20 \mathrm{nM}$ $\left[{ }^{3} \mathrm{H}\right] \mathrm{METH}$. Values shown represent the mean \pm SEM of at least three independent experiments, each performed in triplicate. Results were considered significant if $p<0.05$, one-way ANOVA. ${ }^{a}$ Designates significant difference from 37 and $40^{\circ} \mathrm{C}$. ${ }^{\mathrm{b}}$ Designates significant difference from 34 and $40^{\circ} \mathrm{C}$. ${ }^{\mathrm{c}}$ Designates significant difference from 34 and $37^{\circ} \mathrm{C}$.
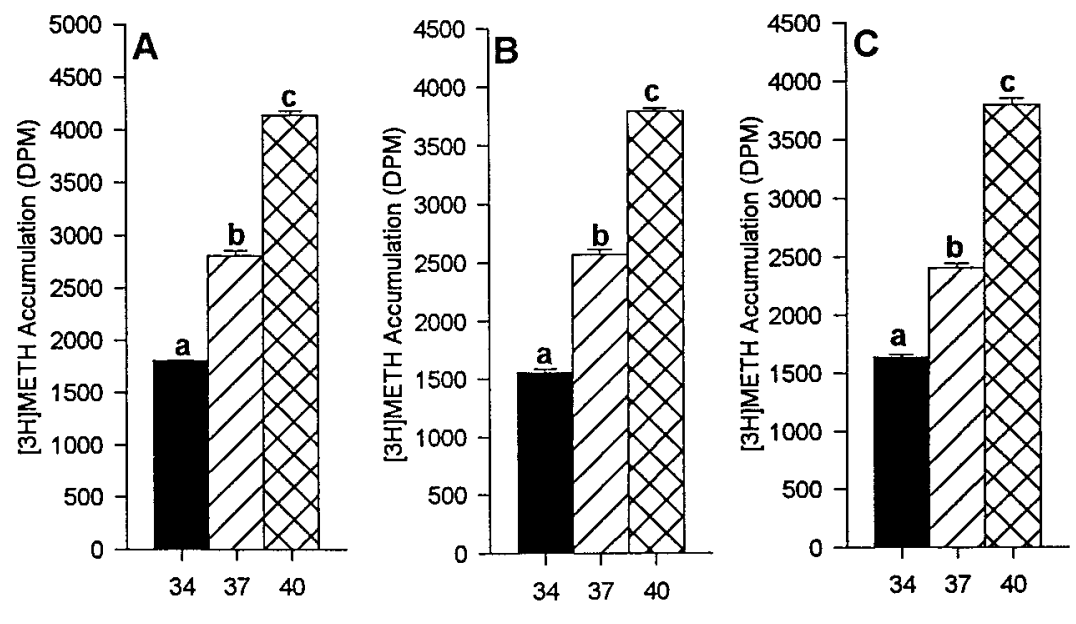

Temperature $\left({ }^{\circ} \mathrm{C}\right)$

Temperature $\left({ }^{\circ} \mathrm{C}\right)$ 


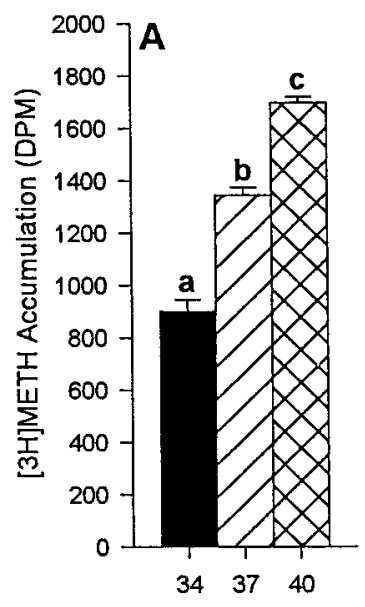

Temperature $\left({ }^{\circ} \mathrm{C}\right)$

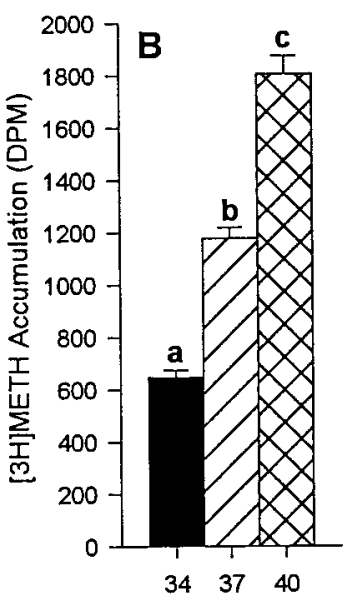

Temperature ( $\left.{ }^{\circ} \mathrm{C}\right)$

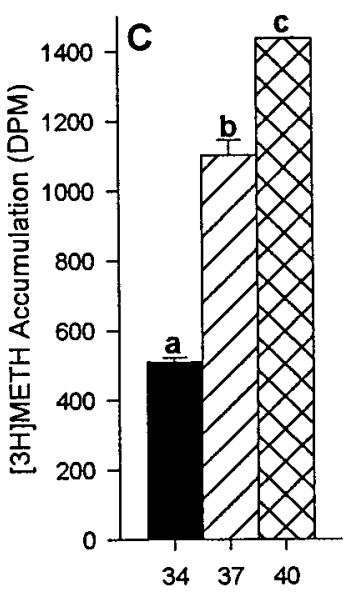

Temperature $\left({ }^{\circ} \mathrm{C}\right)$
Figure 9. Effect of temperature on DAT-mediated $\left[{ }^{3} \mathrm{H}\right] \mathrm{METH}$ accumulation in embryonic mesencephalic cells. The experiment was performed as described in Materials and Methods. Significantly greater METH accumulation was observed at higher temperatures at all concentrations of $\operatorname{METH}(0.1,1$, and $10 \mu \mathrm{M} ; A-C$, respectively) tested in the presence of $20 \mathrm{nM}$ $\left[{ }^{3} \mathrm{H}\right]$ METH. Values shown represent the mean \pm SEM of at least three independent experiments, each performed in triplicate. Results were considered significant if $p<0.05$, one-way ANOVA. 'Designates significant difference from 37 and $40^{\circ} \mathrm{C}$. ${ }^{b}$ Designates significant difference from 34 and $40^{\circ} \mathrm{C}$. ${ }^{c}$ Designates significant difference from 34 and $37^{\circ} \mathrm{C}$.
METH-induced DA neurotoxicity, as indexed in that model system (Kim et al., 2000).

The observation that increased temperature leads to increased DAT function does not preclude the possibility that other mechanisms potentially involved in METH-induced DA neurotoxicity are also influenced by temperature. For example, increased temperature may be associated with increased METH-induced DA release or redistribution, possibly leading to increased formation of reactive oxidative species (Cubells et al., 1994; Hirata et al., 1996; Huang et al., 1997; Fumagalli et al., 1999). Increased temperature is also likely to be associated with increased metabolic demand, and this could also influence METH neurotoxicity (Chan et al., 1994; Albers et al., 1996; Bowyer et al., 1996; Huang et al., 1997; Stephans et al., 1998; Burrows et al., 2000), although results of studies evaluating the role of energy consumption in METH neurotoxicity have not always been consistent (Chan et al., 1994; Callahan and Ricaurte, 1998). Alternatively, higher temperatures may increase the release of excitatory amino acids (EAAs) potentially involved in METH-induced DA injury (Sonsalla et al., 1989, 1991; Stephans and Yamamoto, 1994). However, because the ability of EAA antagonists to protect from METH neurotoxicity appears to be largely dependent on their hypothermic effects (Bowyer et al., 1994; Miller and O'Callaghan, 1994), the role of EAAs in METH neurotoxicity is uncertain. Nonetheless, these or other as yet unidentified mechanisms or processes underlying METH neurotoxicity could all theoretically be influenced by temperature in a manner that would lead to an exacerbation of METH-induced neurotoxic injury.

Findings from the present study also shed light on neurotoxic processes induced by the dopaminergic neurotoxin $\mathrm{MPP}^{+}$(Langston et al., 1983, 1984; Heikkila et al., 1984). In particular, a key event in the expression of the neurotoxicity of MPTP is the active uptake of $\mathrm{MPP}^{+}$into dopaminergic neurons (Javitch et al., 1985; Melamed et al., 1985; Chiba et al., 1985). Like METH, a positive relationship between DAT function and MPTP-induced neurotoxicity has been revealed (Ricaurte et al., 1985; Gainetdinov et al., 1997; Bezard et al., 1999; Donovan et al., 1999). However, in contrast to what is observed with METH, hypothermia enhances MPTP-induced neurotoxicity in mice, via an unknown mechanism (Freyaldenhoven et al., 1995; Moy et al., 1998). Results from the present study indicate that the ability of hypothermia to exacerbate MPTP-induced DA neurotoxicity is not caused by the increase in the transmembrane $\mathrm{MPP}^{+}$incorporation. Other factors capable of increasing the bioavailability of MPTP in brain under conditions of hypothermia are likely to be responsible for this apparent paradox. Nevertheless, the fact that with relatively small increases in temperature, there are significant increases in the accumulation of a potent DA neurotoxin such as $\mathrm{MPP}^{+}$suggests that the present findings may have relevance to idiopathic disease processes involving brain DA neurons (e.g., Parkinson's disease).
In summary, data from the current study indicate that small, physiologically relevant changes in temperature designed to parallel those in METH-treated animals can significantly influence DAT function and DAT-mediated METH cellular accumulation measured in isolated cell systems. Given the central role of the DAT in METH-induced DA neurotoxicity, it seems likely that temperature exerts its effect on METH-induced DA neurotoxicity, at least in part, at the level of the DAT. The fact that temperature also influences $\mathrm{MPP}^{+}$accumulation raises the possibility that the present results may be of relevance to pathophysiological insults related to DAT-mediated entry of toxic species. Finally, it seems likely that the present studies have implications for other toxic amphetamine derivatives (e.g., MDMA), because the neurotoxic effects of these drugs are also highly dependent on intact neurotransporter function (Rudnick and Wall, 1992; Shankaran et al., 1999) and influenced by temperature (Malberg and Seiden, 1998).

\section{REFERENCES}

Albers DS, Sonsalla PK (1995) Methamphetamine-induced hyperthermia and dopaminergic neurotoxicity in mice: pharmacological profile of protective and nonprotective agents. J Pharmacol Exp Ther 275:1104-1114.

Albers DS, Zeevalk GD, Sonsalla PK (1996) Damage to dopaminergic nerve terminals in mice by combined treatment of intrastriatal malonate with systemic methamphetamine or MPTP. Brain Res 718:217-220.

Ali SF, Newport GD, Holson RR, Slikker Jr W, Bowyer JF (1994) Low environmental temperatures or pharmacologic agents that produce hypothermia decrease methamphetamine neurotoxicity in mice. Brain Res 658:33-38.

Bennett BA, Hyde CE, Pecora JR, Clodfelter JE (1993) Differing neurotoxic potencies of methamphetamine, mazindol, and cocaine in mesencephalic cultures. J Neurochem 60:1444-1452.

Bennett BA, Hollingsworth CK, Martin RS, Harp JJ (1998) Methamphetamine-induced alterations in dopamine transporter function. Brain Res 782:219-227.

Bezard E, Gross CE, Fournier MC, Dovero S, Bloch B, Jaber M (1999) Absence of MPTP-induced neuronal death in mice lacking the dopamine transporter. Exp Neurol 155:268-273.

Bowyer JF, Tank AW, Newport GD, Slikker Jr W, Ali SF, Holson RR (1992) The influence of environmental temperature on the transient effects of methamphetamine on dopamine levels and dopamine release in striatum. J Pharmacol Exp Ther 260:817-824.

Bowyer JF, Davies DL, Schmued L, Broening HW, Newport GD, Slikker Jr W, Holson RR (1994) Further studies of the role of hyperthermia in methamphetamine neurotoxicity. J Pharmacol Exp Ther 268:1571-1580.

Bowyer JF, Clausing P, Schmued L, Davies DL, Binienda Z, Newport GD, Scallet AC, Slikker Jr W (1996) Parenterally administered 3-nitropropionic acid and amphetamine can combine to produce damage to terminals and cell bodies in the striatum. Brain Res 712:221-229.

Broening HW, Bowyer JF, Slikker Jr W (1995) Age-dependent sensitivity of rats to the long-term effects of the serotonergic neurotoxicant $(+/-)$ 3,4-methylenedioxymethamphetamine (MDMA) correlates with the magnitude of the MDMA-induced thermal response. J Pharmacol Exp Ther 275:325-333.

Broening HW, Pu C, Vorhees CV (1997) Methamphetamine selectively damages dopaminergic innervation to the nucleus accumbens core while sparing the shell. Synapse 27:153-160.

Burrows KB, Nixdorf WL, Yamamoto BK (2000) Central administration 
of methamphetamine synergizes with metabolic inhibition to deplete striatal monoamines. J Pharmacol Exp Ther 292:853-860.

Callahan BT, Ricaurte GA (1998) Effect of 7-nitroindazole on body temperature and methamphetamine-induced dopamine toxicity. NeuroReport 9:2691-2695.

Callahan BT, Kim S, Yuan J, Ricaurte G (2000) Effect of dopamine uptake blockers on methamphetamine toxicity in primary mesencephalic cultures. Soc Neurosci Abstr, in press.

Cappon GD, Morford LL, Vorhees CV (1997) Ontogeny of methamphetamine-induced neurotoxicity and associated hyperthermic response. Brain Res Dev Brain Res 103:155-162.

Chan P, Di Monte DA, Luo J-J, Delanney LE, Irwin I, Langston JW (1994) Rapid ATP loss caused by methamphetamine in the mouse striatum: relationship between energy impairment and dopaminergic neurotoxicity. J Neurochem 62:2484-2487.

Chiba K, Trevor AJ, Castagnoli Jr N (1985) Active uptake of MPP ${ }^{+}$, a metabolite of MPP + , by brain synaptosomes. Biochem Biophys Res Commun 128:1228-1232.

Clausing P, Bowyer JF (1999) Time course of brain temperature and caudate/putamen microdialysate levels of amphetamine and dopamine in rats after multiple doses of D-amphetamine. Ann NY Acad Sci 890:495-504

Cubells JF, Rayport S, Rajendran G, Sulzer D (1994) Methamphetamine neurotoxicity involves vacuolation of endocytic organelles and dopaminedependent intracellular oxidative stress. J Neurosci 14:2260-2271.

Donovan DM, Miner LL, Perry MP, Revay RS, Sharpe LG, Przedborski S, Kostic V, Philpot RM, Kirstein CL, Rothman RB, Schindler CW, Uh GR (1999) Cocaine reward and MPTP toxicity: alteration by regional variant dopamine transporter overexpression. Mol Brain Res 73:37-49.

Ellison G, Eison MS, Huberman HS, Daniel F (1978) Long-term changes in dopaminergic innervation of caudate nucleus after continuous amphetamine administration. Science 201:276-278.

Frey K, Kilbourn M, Robinson T (1997) Reduced striatal vesicular monoamine transporters after neurotoxic but not after behaviorally-sensitizing doses of methamphetamine. Eur J Pharmacol 334:273-279.

Freyaldenhoven TE, Ali SF, Hart RW (1995) MPTP and MPP ${ }^{+}$-induced effects on body temperature exhibit age- and strain-dependence in mice. Brain Res 688:161-170.

Fukumura M, Cappon GD, Pu CF, Broening HW, Vorhees CV (1998) A single dose model of methamphetamine-induced neurotoxicity in rats: effects on neostriatal monoamines and glial fibrillary acidic protein. Brain Res 806:1-7.

Fumagalli F, Gainetdinov RR, Valenzano KJ, Caron MG (1998) Role of dopamine transporter in methamphetamine-induced neurotoxicity: evidence from mice lacking the transporter. J Neurosci 18:4861-4869.

Fumagalli F, Gainetdinov RR, Wang YM, Valenzano KJ, Miller GW, Caron MG (1999) Increased methamphetamine neurotoxicity in heterozygous vesicular monoamine transporter 2 knock-out mice. J Neurosci 19:2424-2431.

Gainetdinov RR, Fumagalli F, Jones SR, Caron MG (1997) Dopamine transporter is required for in vivo MPTP neurotoxicity: evidence from mice lacking the transporter. J Neurochem 69:1322-1325.

Gibb JW, Hanson GR, Johnson M (1994) Neurochemical mechanisms of toxicity. In: Amphetamine and its analogs (Cho AK, Segal DS, eds), pp 269-295. Los Angeles: Academic.

Heikkila RE, Manzino L, Cabbat FS, Duvoisin RC (1984) Protection against the dopaminergic neurotoxicity of 1-methyl-4-phenyl-1,2,5,6tetrahydropyridine by monoamine oxidase inhibitors. Nature 311:467-469.

Hirata H, Cadet JL (1997) p53-knockout mice are protected against the long-term effects of methamphetamine on dopaminergic terminals and cell bodies. J Neurochem 69:780-790.

Hirata H, Ladenheim B, Carlson E, Epstein C, Cadet JL (1996) Autoradiographic evidence for methamphetamine-induced striatal dopaminergic loss in mouse brain: attenuation in $\mathrm{CuZn}$-superoxide dismutase transgenic mice. Brain Res 714:95-103.

Huang NK, Wan FJ, Tseng CJ, Tung CS (1997) Nicotinamide attenuates methamphetamine-induced striatal dopamine depletion in rats. NeuroReport 8:1883-1885.

Javitch JA, D’Amato RJ, Strittmatter SM, Snyder SH (1985) Parkinsonisminducing neurotoxin, N-methyl-4-phenyl-1,2,3,6 -tetrahydropyridine: uptake of the metabolite $N$-methyl-4-phenylpyridine by dopamine neurons explains selective toxicity. Proc Natl Acad Sci USA 82:2173-2177.

Kim S, Westphalen R, Callahan B, Hatzidimitriou G, Yuan J, Ricaurte GA (2000) Toward development of an in vitro model of methamphetamineinduced dopamine nerve terminal toxicity. J Pharmacol Exp Ther 293:625-633.

Koob GF, Bloom FE (1988) Cellular and molecular mechanisms of drug dependence. Science 242:715-723.

Langston JW, Ballard P, Tetrud JW, Irwin I (1983) Chronic Parkinsonism in humans due to a product of meperidine-analog synthesis. Science 219:979-980.

Langston JW, Forno LS, Rebert CS, Irwin I (1984) Selective nigral toxicity after systemic administration of 1-methyl-4-phenyl-1,2,5,6-tetrahydropyrine (MPTP) in the squirrel monkey. Brain Res 292:390-394.

Lew R, Malgrange B, Ricaurte GA, Seiden LS (1998) Evidence for mechanism of action of neurotoxicity of amphetamine related compounds. In Highly selective neurotoxins: basic and clinical applications (Kostrzewa RM, ed), pp 235-268. Totowa, NJ: Humana.
Liang NY, Rutledge CO (1982) Comparison of the release of [3H]dopamine from isolated corpus striatum by amphetamine, fenfluramine and unlabelled dopamine. Biochem Pharmacol 31:983-992.

Lorez H (1981) Fluorescence histochemistry indicates damage of striatal dopamine nerve terminals in rats after multiple doses of methamphetamine. Life Sci 28:911-916.

Malberg JE, Seiden LS (1998) Small changes in ambient temperature cause large changes in 3,4-methylenedioxymethamphetamine (MDMA)induced serotonin neurotoxicity and core body temperature in the rat. J Neurosci 18:5086-5094.

Marek GJ, Vosmer G, Seiden LS (1990) Dopamine uptake inhibitors block long-term neurotoxic effects of methamphetamine upon dopaminergic neurons. Brain Res 513:274-279.

McCann UD, Wong DF, Yokoi F, Villemagne V, Dannals RF, Ricaurte GA (1998) Reduced striatal dopamine transporter density in abstinent methamphetamine and methcathinone users: evidence from positron emission tomography studies with [ $\left.{ }^{11} \mathrm{C}\right] \mathrm{WIN}-35,428$. J Neurosci 18:8417-8422.

Melamed E, Rosenthal J, Cohen O, Globus M, Uzzan A (1985) Dopamine but not norepinephrine or serotonin uptake inhibitors protect mice against neurotoxicity of MPTP. Eur J Pharmacol 116:179-181.

Miller DB, O'Callaghan JP (1994) Environment-, drug- and stressinduced alterations in body temperature affect the neurotoxicity of substituted amphetamines in the C57BL/6J mouse. J Pharmacol Exp Ther 270:752-760.

Miller GW, Gainetdinov RR, Levey AI, Caron MG (1999) Dopamine transporters and neuronal injury. Trends Pharmacol Sci 20:424-429.

Moy LY, Albers DS, Sonsalla PK (1998) Lowering ambient or core body temperature elevates striatal $\mathrm{MPP}^{+}$levels and enhances toxicity to dopamine neurons in MPTP-treated mice. Brain Res 790:264-269.

Pifl C, Giros B, Caron MG (1993) Dopamine transporter expression confers cytotoxicity to low doses of the Parkinsonism-inducing neurotoxin 1-methyl-4-phenylpyridinium. J Neurosci 13:4246-4253.

$\mathrm{Pu}$ C, Fisher JE, Cappon GD, Vorhees CV (1994) The effects of amfonelic acid, a dopamine uptake inhibitor, on methamphetamine-induced dopaminergic terminal degeneration and astrocytic response in rat striatum. Brain Res 649:217-224.

Ricaurte GA, Guillery RW, Seiden LS, Schuster CR, Moore RY (1982) Dopamine nerve terminal degeneration produced by high doses of methylamphetamine in the rat brain. Brain Res 235:93-103.

Ricaurte GA, Fuller RW, Perry KW, Seiden LS, Schuster CR (1983) Fluoxetine increases long-lasting neostriatal dopamine depletion after administration of D-methamphetamine and D-amphetamine. Neuropharmacology 22:1165-1169.

Ricaurte GA, Seiden LS, Schuster CR (1984) Further evidence that amphetamines produce long-lasting dopamine neurochemical deficits by destroying dopamine nerve fibers. Brain Res 303:359-364.

Ricaurte GA, Langston JW, DeLanney LE, Irwin I, Brooks JD (1985) Dopamine uptake blockers protect against the dopamine depleting effect of 1-methyl-4-phenyl-1,2,3,6-tetrahydropyridine (MPTP) in the mouse striatum. Neurosci Lett 59:259-264.

Ricaurte GA, Martello AL, Katz JL, Martello MB (1992) Lasting effects of (+-)-3,4-methylenedioxymethamphetamine (MDMA) on central serotonergic neurons in nonhuman primates: neurochemical observations. J Pharmacol Exp Ther 261:616-622.

Ritz MC, Lamb RJ, Goldberg SR, Kuhar MJ (1987) Cocaine receptors on dopamine transporters are related to self-administration of cocaine. Science 237:1219-1223.

Rudnick G, Wall SC (1992) The molecular mechanism of "ecstasy" [3,4methylenedioxy-methamphetamine (MDMA)]: serotonin transporters are targets for MDMA-induced serotonin release. Proc Natl Acad Sci USA 89:1817-1821.

Seiden LS, Ricaurte GA (1987) Neurotoxicity of methamphetamine and related drugs. In: Psychopharmacology: the third generation of progress (Meltzer HY, ed), pp 359-366. New York: Raven.

Shankaran M, Yamamoto BK, Gudelsky GA (1999) Involvement of the serotonin transporter in the formation of hydroxyl radicals induced by 3,4-methylenedioxymethamphetamine. Eur J Pharmacol 385:103-110.

Shimada S, Kitayama S, Lin CL, Patel A, Nanthakumar E, Gregor P, Kuhar M, Uhl G (1991) Cloning and expression of a cocaine-sensitive dopamine transporter complementary DNA. Science 254:576-578.

Shimoda K, Sauve Y, Marini A, Schwartz JP, Commissiong JW (1992) A high percentage yield of tyrosine hydroxylase-positive cells from rat E14 mesencephalic cell culture. Brain Res 586:319-331.

Sonsalla PK, Nicklas WJ, Heikkila RE (1989) Role for excitatory amino acids in methamphetamine-induced nigrostriatal dopaminergic toxicity. Science 243:398-400.

Sonsalla PK, Riordan DE, Heikkila RE (1991) Competitive and noncompetitive antagonists at $\mathrm{N}$-methyl-D-aspartate receptors protect against methamphetamine-induced dopaminergic damage in mice. J Pharmacol Exp Ther 256:506-512.

Sonsalla PK, Jochnowitz ND, Zeevalk GD, Oostveen JA, Hall ED (1996) Treatment of mice with methamphetamine produces cell loss in the substantia nigra. Brain Res 738:172-175. 
Stephans SE, Yamamoto BK (1994) Methamphetamine-induced neurotoxicity: roles for glutamate and dopamine efflux. Synapse 17:203-209.

Stephans SE, Whittingham TS, Douglas AJ, Lust WD, Yamamoto BK (1998) Substrates of energy metabolism attenuate methamphetamineinduced neurotoxicity in striatum. J Neurochem 71:613-621.

Villemagne V, Yuan J, Wong DF, Dannals RF, Hatzidimitriou G, Mathews WB, Ravert HT, Musachio J, McCann UD, Ricaurte GA (1998) Brain dopamine neurotoxicity in baboons treated with doses of methamphetamine comparable to those recreationally abused by humans: evidence from [11C]W IN-35,428 positron emission tomography studies and direct in vitro determinations. J Neurosci 18:419-427.

Volkow ND, Chang L, Wang GJ, Fowler JS, Franceschi D, Gatley SJ, Wong
CT, Hitzemann RJ, Pappas NR (1999) In vivo evidence that methamphetamine abuse produces long-lasting changes in dopamine transporters in human brain. J Nucl Med 40:110.

Woolverton WL, Ricaurte GA, Forno LS, Seiden LS (1989) Long-term effects of chronic methamphetamine administration in rhesus monkeys. Brain Res 486:73-78.

Zaczek R, Culp S, De SE (1991a) Interactions of [3H]amphetamine with rat brain synaptosomes. II. Active transport. J Pharmacol Exp Ther 257:830-835

Zaczek R, Culp S, Goldberg H, McCann DJ, De SE (1991b) Interactions of $\left[{ }^{3} \mathrm{H}\right]$ amphetamine with rat brain synaptosomes. I. Saturable sequestration. J Pharmacol Exp Ther 257:820-829. 